\title{
JAGODA KUREK
}

Uniwersytet Warszawski

\section{ZNACZENIE SEOWA W MAGICZNYCH RYTUALACH WICCA}

Magia, której efektywności i siły od wieków upatrywano między innymi w formułach słownych, kojarzona jest przede wszystkim ze społecznościami pierwotnymi ${ }^{1}$ i kulturą ludową ${ }^{2}$. Zaklęcia, inwokacje czy przekleństwa stanowią najbardziej archaiczną formę wykorzystania języka performatywnego. Postmodernistyczna cywilizacja europejska daleka jest od wizji świata opierającej się na sprawczym oddziaływaniu słowa magicznego na rzeczywistość. W języku odnajdujemy co prawda relikty ludowych wierzeń (jak klątwy, złorzeczenia czy błogosławieństwa), jednak powtarzane nieświadomie, odarte z pierwotnej potęgi, stanowiące jedynie pozbawioną treści formę. Nic dziwnego - scjentystyczne myślenie, które zdominowało sferę publiczną, wyklucza realne istnienie magii jako takiej, a co za tym idzie - odbiera moc zaklęciom. Jednak od kilkudziesięciu lat w różnych krajach cywilizacji zachodu (zarówno w Europie jak i Stanach Zjednoczonych) powstają bądź ujawniają się ruchy społeczno-religijne, które powracają do etnicznych wierzeń lub w sposób eklektyczny łączą elementy zaczerpnięte z różnych kultów i filozofii, tworząc nowe jakości. Zarówno rodzimowiercy ${ }^{3}$ jak i neopoganie ${ }^{4}$ powracają do tzw. światopoglądu magicznego (mitycznego) ${ }^{5}$. Zachodzi ciekawe, niespotykane dotąd zjawisko połączenia pierwotnej i nowożytnej optyki, co pozwala na funkcjonowanie współczesnego słowa magicznego w pełnym jego wymiarze.

Celem niniejszego artykułu jest zaprezentowanie języka performatywnego, materializowanego $\mathrm{w}$ formie zaklęć, modlitw czy inwokacji i wykorzystywanego podczas magicznych rytuałów współczesnych czarownic ${ }^{6}$, wyznających neopogańską religię wicca.

Mówiąc o języku performatywnym, posiłkuję się teorią Johna Austina, określającego w ten sposób akty mowy obdarzone (w odróżnieniu od wypowiedzi spełniających funkcje komunikacyjne) charakterystyczną sprawczą mocą (Austin 1975: 68). Zbieżny pogląd prezentuje Renata Grzegorczykowa, kiedy wypowiedzi o charakterze performatywnym przyrównuje do „stwarzania nowych stanów rzeczy przez słowa (Grzegorczykowa 1995: 13). Według badaczki nie są one zwyczajną informacją, ale posiadają moc sprawczą bądź wiążącą (a przynamniej jest im takowa przypisywana). Nie opisują rzeczywistości, ale ją tworzą (Grzegorczykowa 1995: 13).

\footnotetext{
${ }^{1} \mathrm{~W}$ niniejszym tekście będę posługiwać się terminami „społeczeństwo pierwotne”, „człowiek pierwotny” w rozumieniu zasugerowanym przez Claude’a Lévi-Straussa (Por. Lévi-Strauss 1969: 49).

${ }^{2}$ Poprzez pojęcie „kultura ludowa” rozumiem duchową oraz materialną kulturę specyficznej warstwy społecznej, której członkowie utrzymywali się z pracy na roli. Według Justyny Straczuk „Praca ta odznaczająca się niezwykle bogatą symboliką, była podstawą formułowania chłopskiego światopoglądu, systemu wartości, obrzędowości, zasad życia społecznego" (Por. Straczuk 2006: 8).

${ }^{3}$ Termin „rodzimowierstwo” określa system etnicznych wierzeń odwołujących się do przedchrześcijańskich wartości, pochodzących z danego narodu, plemienia, ojczyzny, miejsca itd. (Pełka 1999: 115-133).

${ }^{4}$ „Neopogaństwo” to termin niezwykle szeroki, określający zarówno mniej lub bardziej skonwencjonalizowane religie, jak i nurty eklektyczne, dla których typowa jest swoboda w przyjmowaniu elementów duchowych i światopoglądowych.

5 „Światopogląd magiczny” rozumiem za J.S. Wasilewskim jako intelektualne podłoże dla wszelkich działań magicznych, charakteryzujące się spójnością komponentów dominujących w wizji świata danej kultury (Wasilewski 1989: 15); zaś za jego podstawię przyjmuję za Anną Engelking ,jedność człowieka i przyrody, brak dualizmu, podziału podmiot - przedmiot" (Engelking 2010: 45).

${ }^{6}$ Wyznawcy wicca określają się mianem ,czarownica”, bez względu na płeć. Religia ta narodziła się w Anglii, gdzie wiccanie nazywani są jedną formą rzeczownika „witch”. Polscy wyznawcy starają się zachować oryginalną formę, nie doszukując się polskiego odpowiednika w rodzaju męskim. Słowo „czarownik” jest czasami używane do określania wyznawców innych współczesnych systemów, bazujących na uprawianiu magii ceremonialnej (np. kabały czy magii enochiańskiej).
} 
Tekst prezentuje analizę słowa magicznego w wiccańskich rytuałach na podstawie badań terenowych przeprowadzonych w 2016 i 2017 roku, głównie na terenie Warszawy, lecz nie tylko. Bogaty materiał został zebrany podczas uczestnictwa w tak zwanym Wiccanisku - wydarzeniu organizowanym przez administratorów strony Wiccański krąg w Stacji Wolimierz na Dolnym Śląsku. Wiccanisko odbywało się w dniach 25-28 sierpnia 2016 roku, a jego celem była popularyzacja religii wicca, rzemiosła magicznego oraz przekazywanie rzetelnej wiedzy na temat czarostwa ${ }^{8}$. Na event składał się szereg wykładów i warsztatów, oraz tzw. rytuały otwarte ${ }^{9}$. Większość badań została jednak przeprowadzona przez rok systematycznych, cotygodniowych spotkań z wyznawcami wicca (organizowanych w Warszawie, przez czarownice związane z Wiccańskim kręgiem) oraz udział w rytuałach otwartych Warszawskiej Grupy Obrzędowej Wiccańskiego Koła Roku ${ }^{10}$. Podstawowymi technikami badawczymi były wywiady etnograficzne i obserwacja uczestnicząca.

Artykuł poddaje również analizie materiały zastane w postaci publikacji wiccan na stronach internetowych, co pozwala uzupełnić informacje zdobyte podczas badań.

\section{Wicca - definicja i charakterystyka ruchu religijno-kulturowego}

Czarostwo to niełatwy do zdefiniowania nurt neopogaństwa. Różnorodność poszczególnych odłamów, liczne niuanse i wieloaspektowość tego ruchu stwarza badaczom szerokie pole do analizy. Niestety, nie powstało dotąd wiele prac naukowych, szczególnie w Polsce, które uwzględniałyby to zróżnicowanie i oddawały istotę zjawiska. Najbardziej wyczerpującym opracowaniem naukowym okazuje się być artykuł Macieja Witulskiego pt. Próba zdefiniowania i usystematyzowania ruchu wicca ${ }^{11}$. Niezwykle pomocna okazała się być również pozycja zagraniczna Margot Adler Drawing down the Moon. Witches, Druids, Goddess-Worshippers, and Other Pagans in America Today, Revised and Extended Edition.

${ }^{7}$ Wiccański krąg to strona internetowa istniejąca od czerwca 2011 roku, prowadzona przez wyznawców odłamu tradycyjnego (różne nurty Wicca omawiam w dalszej części artykułu). Oprócz forum, na którym możliwa jest wymiana informacji i poglądów, na stronie można znaleźć szereg tekstów zawierających podstawowe informacje na temat Wicca, szerokopojętej duchowości i magii (zob. wiccanski-krag.com).

${ }^{8}$ Termin ,czarostwo” występuje jako synonim określenia ,wicca” (Witulski 2009: 7).

${ }^{9}$ Tradycyjny odłam wicca nie dopuszcza do rytuałów osób nieinicjowanych. Wyjątek stanowią rytuały otwarte, które przybierają nieco inną formę, niż rytuały właściwe (różne nurty Wicca omawiam w dalszej części artykułu). Wnioski i spostrzeżenia autorki na podstawie przeprowadzonych badań i obserwacji.

${ }^{10}$ Grupa składała się z kobiet i mężczyzn, w większości nieinicjowanych (istotę inicjacji omawiam w dalszej części artykułu), zainteresowanych czarostwem i szerokopojętym neopogaństwem. Rytuały były jednakże często przeprowadzane przez inicjowaną arcykapłankę jednego z polskich kowenów (istotę kowenu omawiam w dalszej części artykułu).

${ }^{11} \mathrm{Na}$ polskim gruncie trudno o rzetelne opracowania naukowe w tematyce religii czarownic. Pomijając opracowanie M.Witulskiego, definicje są nieadekwatne bądź niewystarczające. Remigiusz Okraska podaje: „Szczególnie popularny jest tzw. wiccanizm, czyli nurt odwołujący się do tradycji czarownic, które w myśl tej teorii były kapłankami dawnego kultu płodności. Rozwój wiccanizmu datuje się od lat 20. (kiedy to egiptolożka Margaret Murray postawiła tezę - nb. obaloną później przez innych naukowców - że średniowieczne czarownice były kapłankami pogańskiego kultu płodności, jednak nabrał mocy w trzydzieści lat później, nie będąc początkowo związany z ruchem feministycznym. Silnie wyeksponowany pierwiastek kobiecy sprawił, że wkrótce zyskał sporą popularność w radykalnych odłamach feminizmu. Wiccanizm podkreśla przewagę pierwiastka żeńskiego (lunarnego) nad męskim (solarnym), próbuje nawiązać do dawnych, matriarchalnych wierzeń i poszukuje w mitologiach przedchrześcijańskich elementów tożsamych z tą teorią" (Okraska 2001: 42). Podobną tezę przedstawia Jarosław Tomasiewicz (Tomasiewicz 1994: 99). Jest to opis nieprecyzyjny, gdyż wiccanie w przeważającej większości wyznają równość obu kosmicznych pierwiastków: męskiego i żeńskiego. Stereotyp wicca jako religii kobiet zaistniał przez media promujące wizerunek kobiety-czarownicy, co zaowocowało obiegową opinią o feministycznych charakterze tego ruchu (Witulski 2009: 7). Leonard Pełka definiuje czarostwo w sposób bardzo ogólny, nie ujmując informacji o doktrynie, strukturze czy kulcie: „Neopogańska religia natury oparta na czarostwie (z zaakcentowaniem magii seksualnej) i technikach terapii duchowej” (Pełka 200: 21). Powstała również książka Renaty Furman Wicca i wiccanie. Od tradycji do wirtualnej wspólnoty, wysoce krytykowana przez samych wyznawców (Por. recenzja rzeczonej książki autorstwa Enneny, http://wicca. pl/?art=42, dostęp: 11.03.2019). 
Tekst poddaje analizie materiały źródłowe (tzw. źródła zastane), które stanowią strony internetowe administrowane przez samych wyznawców, szczególnie wicca.pl (prowadzona przez pierwszą polską wiccankę o pseudonimie Ennena, uznawaną w Polsce za autorytet $\mathrm{w}$ dziedzinie czarostwa) oraz wspominany już wiccanski-krag.com.

Wicca jest obecnie jedną z najprężniej rozpowszechniających się religii neopogańskich na świecie (Witulski 2009: 5). Dynamizm rozwoju zaskakuje, od lat 50 XX wieku kult, który narodził się w Wielkiej Brytanii, zalał całą Europę i Stany Zjednoczone. Margot Adler, amerykańska autorka opisująca religię czarownic, definiuje ją w następujący sposób:

Wyznawcy czerpią swoje inspiracje z przedchrześcijańskich źródeł, europejskiego folkloru i mitologii. Uważają siebie za kapłanów i kapłanki dawnej europejskiej szamanistycznej religii natury, która czciła Boginię, utożsamianą z antyczną Matką Boginią w jej trzech aspektach: Panny, Matki i Staruchy. Wiele tradycji Rzemiosła czci także Boga, identyfikowanego z dawnym Panem Zwierzyny, Bogiem Łowów, Bogiem Śmierci i Panem Lasów (Adler 1986: 10-11).

Oprócz odwołań do przedchrześcijańskich kultów europejskich, istotne są również wpływy wschodnie: koncepcja reinkarnacji, joga czy medytacja. Wicca nierzadko inkorporuje też elementy kabały czy gnozy (Witulski 2009: 8). Idąc za definicją Witulskiego:

Wicca to określenie szeroko rozumianej, współczesnej religii czarownic. Na ogół jest to religia politeistyczna, skupiona na kulcie Rogatego Boga i Bogini o Trzech Twarzach, praktyce magii pozytywnej, wierze w reinkarnację, przestrzeganiu wiccańskiej rady (czyń, co chcesz, o ile kogoś nie skrzywdzisz), celebrowaniu świąt lunarnych (12-13 pełni księżyca w roku) oraz solarnych (8 do-rocznych związanych ze zmianami w cyklu słonecznym). Od każdej wymienionej cechy można jednak znaleźć wyjątki, szczególnie w nurtach eklektycznych. Wicca wyznawana jest indywidualnie (tzw. solitary path wicca), grupowo (kowen) $)^{12}$ lub rodzinnie (Witulski 2009: 9).

Sami respondenci definiują czarostwo w następujący sposób:

\section{J.K: Jak opisałabyś swoją religię? Czym jest wicca?}

Magdalena: To ścieżka życia i rozwoju duchowego, wewnętrznego a nawet osobistego czy emocjonalnego. To możliwość stawania w swojej mocy, bycia tym, kim czuję, że jestem. To rzemiosło, pozwalające wzrastać w sztuce magii. To wspólnota, rodzina, więzi, pozwalajace nakarmić duszę. To misterium, dzięki któremu doświadczam boskości, również tej boskości w sobie. To równowaga pomiędzy tym co kobiece, a tym co męskie (wyw. II, Magdalena).

Korzenie czarostwa sięgają lat 50. XX wieku, kiedy to Gerald B. Gardner ${ }^{13}$ założył pierwszy kowen w New Forest w Wielkiej Brytanii. Dzisiaj istnieje wiele nurtów wicca, które można podzielić na dwie, znacznie różniące się od siebie gałęzie: wicca tradycyjne (British Traditional Witchcraft) ${ }^{14}$, stanowiące inicjacyjną religię misteryjną (Ennena) oraz

${ }^{12}$ Kowen (ang. coven) to grupa czarownic wspólnie praktykujących rytuały i celebrujących święta. Struktura kowenu charakterystyczna jest dla tradycyjnej ścieżki wicca, która wymaga inicjacji oraz odpowiedniego przysposobienia. Kowen może liczyć sobie od kilku do trzynastu osób. Na jego czele najczęściej stoi arcykapłan i arcykapłanka.

${ }^{13}$ Gerald Brousseau Gardner (1884-1964) - brytyjski okultysta, antropolog-amator, publicysta i czarownica. Swoim dorobkiem pisarskim, zwłaszcza Współczesnym czarownictwem (1954), przyczynił się do powstania wicca (Witulski 2009: 7-14).

${ }^{14}$ Główne ścieżki należące do odłamu tradycyjnego to tradycja gardneryjska (od Geralda B. Gardnera) i aleksandryjska (założona przez Aleksa Sandersa). Alexander Sanders (właśc. Orell Alexander Carter, $1926-$ 1988) wprowadził zmiany w rytuałach gardneriańskich. Zapoczątkowana przez niego tradycja uważana jest za bardziej ceremonialną. Zasadniczą rolę w British Traditional Witchcraft odgrywa tajemny rytuał inicjacji, który decyduje o przynależności do danego kowenu. Obie grupy wyróżnia fakt, iż (wbrew obiegowym opiniom) ich przedstawiciele nigdy nie upublicznili swoich rytuałów i misteriów, a treści rzekomo dostępne w internecie wyznawcy komentują jako niekompletne fragmenty lub zupełne apokryfy (Witulski 2009: 14). 
eklektyczne ${ }^{15}$, będące niezwykle szerokim zjawiskiem, w którego skład wchodzą różnorakie nurty charakteryzujące się dużym pluralizmem światopoglądowym, religijnym, doktrynalnym i strukturalnym. W tym miejscu pojawiają się kontrowersje: osoby praktykujące tradycyjną ścieżkę uważają, że tylko inicjowane czarownice mogą nazywać się wyznawcami kultu wicca. Oprócz inicjacji decydującymi elementami według tradycyjnych wiccan są „dziedziczność wiedzy i przekonań” oraz „misteria przekazywane każdej osobie wkraczającej do kręgu", których to brakuje wśród nurtów eklektycznych (Witulski 2009: 13).

Badania będące podstawą niniejszego tekstu zostały przeprowadzone wśród wyznawców czarostwa tradycyjnego, w przeważającej większości wywodzących się z linii Whitecroft ${ }^{16}$. Stanowi ona skądinąd interesującą hybrydę dwóch ścieżek tradycyjnych: gardneriańskiej i aleksandryjskiej (akapit 3/O Wiccańskim kręgu). Nie wyklucza to interpretacji bogatych źródeł, jakimi są publikacje zarówno wiccan tradycyjnych jak i eklektycznych (zob. Elementy rytuaty Deborah Lipp, Czarownictwo dzisiaj Gerdalda Gardnera, Księga czarostwa Bucklanda Raymonda Bucklanda czy Wicca. Przewodnik dla osób indywidualnie praktykujacych magie Scotta Cunninghama), w których odnajdujemy wiele formuł magicznych będących exemplum współczesnej magii językowej.

\section{Rytual czarownic}

Rytuał ${ }^{17}$ to serce wicca. Przez wyznawców uznawany za najistotniejszą część praktyki „katalizator zmian wewnętrznych i medium, które, jeśli przeprowadzony poprawnie, napędza nasz rozwój duchowy" (akapit 1/Rytuał wiccański). Jedna z badanych tłumaczy:

J.K: Czym jest dla ciebie rytuat?

Nefre: Doświadczaniem bogów, duchowości, magii, celebracją świąt, niesamowitym uniesieniem, możliwościq zjednoczenia się z grupq wspaniatych ludzi. Rozwojem duchowym, emocjonalnym i psychicznym (wyw.I, Nefre).

J.K: Czym jest dla Ciebie doznanie mistyczne? Jak doświadczacie wiary?

Maria: Naszym misterium jest rytuat. I podczas rytualu dzieja się różne rzeczy. Przychodza bogowie $i$ każdy doświadcza ich na swój sposób. Nie ma żadnej objawionej prawdy: jest Bóg i Bogini, sa tacy i tacy i masz w to wierzyć. Nie. Sa Wiccanie, którzy w ogóle sa ateistami-uważaja, że to, czego doświadczaja podczas rytuały, to robimy my sami, ludzie, nasze mózgi. Sa wielcy mistycy, no najróżniej (wyw. III, Maria).

Magiczny rytuał jest dla wiccan tradycyjnej ścieżki misterium religijnym. Jego korzenie sięgają pierwotnych, przedchrześcijańskich religii, ale inkorporuje również

${ }^{15}$ Ogólnie przez określenie „,wicca eklektyczne” rozumie się synkretyczne praktyki nieinicjowanych czarownic. Pozwalają one na dużą indywidualizację wyznania poprzez łączenie różnych elementów zaczerpniętych z New Age, tradycyjnego wicca, starożytnych kultów, okultyzmu, magii ludowej, praktyk wschodnich itp. Jak zauważa Witulski: „ruchy eklektyczne odnoszą się do rozmaitych sfer życia. Feministki skupiły się wokół pewnych nurtów (np. dianizm), podobnie homoseksualiści (część tradycji minojskiej)" (Witulski 2009: 18). Powstały też praktyki czerpiące ze spuścizny konkretnych narodów, jak Norse Wicca skupiająca tradycje nordyckie czy analogiczna Slavic Wicca sięgająca do wierzeń słowiańskich (Witulski 2009: 18). Dianizm to nurt wyznający kult Wielkiej Bogini kładący nacisk na pierwiastek i misteria kobiece. Tradycja minojska, zwana braterstwem minojskim, jest męską ścieżką inicjacyjną ,,czczącą życie, mężczyzn kochających mężczyzn i magię w pierwotnym, minojskim kontekście, włączającą także pewne elementy mitologii egejskiej i bliskowschodniej" (Witulski 2009: 6).

${ }^{16}$ Nazwy linii poszczególnych kowenów odnoszą się do miejsc, w których zostały założone. Zgodnie z tym zwyczajem powstały takie nazwy linii jak New Forest Coven czy Bricket Wood Coven (założone przez Gerdalda Gardnera). Kowen założycielski badanych powstał przy ulicy Whitecroft w Londynie.

${ }^{17}$ Rytuał rozumiem za Mirceą Eliade jako „przywracanie pierwotnego mitu i uaktualnianie przeszłości” oraz akt posiadający moc czynnie działającą w świecie i możliwość przekształcania uczestników rytuału (Eliade 1999: 25). 
elementy wierzeń ludowych czy magii wysokiej ${ }^{18}$. Wyznawcy widzą w nim odtworzenie mitu $^{19}$, które ma na celu celebrowanie zmian zachodzących w przyrodzie, ale sprowadzanie go jedynie do tego aspektu jest dużym spłyceniem tematu.

Mimo wielu obostrzeń funkcjonujących w odłamach tradycyjnych, forma jaką przybrać może misterium rytuału jest dość elastyczna. Jak stwierdza Deborah Lipp, amerykańska arcykapłanka inicjowana w tradycyjnym gardneriańskim kowenie czarownic w 1981 roku, można dopasować go do konkretnych preferencji danej grupy (Lipp: 12). Rytuał powinien być spójny z religią (Lipp: 12), ale nie jest niezmiennym konstruktem w całościowym rozumieniu. Praktykuje się go w małych grupach, do trzynastu osób. Koweny, wśród których poczyniono badania, liczyły po sześciu, siedmiu członków. Czarownice duży nacisk kładą na równoważenie żeńskiego i męskiego pierwiastka, dlatego według ogólnej zasady w kręgu powinno stać tyle samo mężczyzn, ile kobiet, jednak w Polsce rzadko się to udaje:

Magdalena: Teoretycznie powinno być nas po równo, tak. I często tak jest w kowenach z Wielkiej Brytanii, gdzie moga sobie na to pozwolić, bo jest tylu Wiccan. Niestety w Polsce ta liczba jest wciąż dość mała, więc żeby w ogóle utworzyć kowen, nie możemy brać pod uwagę tej zasady.

J.K: Czy w takim razie nie zostaje zachwiana równowaga? Rytuat dalej działa?

Magdalena: Tak. Miałby większa jakość, gdyby była zachowana równowaga ptci, ale nie jest ona niezbędna. Wystarczy, że jest kobieta i mężczyzna, żeby wykonać czynności przypisane Bogini $i$ Bogu.

J.K: Jakie to czynności?

Magdalena: No, na przykład kobieta zakreśla krąg, mężczyzna okadza.

J.K: Dlaczego w ten sposób?

Magdalena: Ponieważ krag jest symbolem kobiecości, łona, brzucha. Natomiast kadzidto symbolizuje powietrze - męski żywiot (wyw. II, Magdalena).

Odłamy tradycyjne nie zezwalają na udział osób nieinicjowanych w rytuale misteryjnym, jednakże niekiedy przeprowadzane są tzw. obrzędy otwarte, do których dopuszczony zostaje każdy, kto zechce stanąć w kręgu. Dzięki obserwacji powyższych można pokusić się o krótką analizę tego dwojakiego: magicznego i religijnego zjawiska ${ }^{20}$.

Przeprowadzane przez grupę badaną rytuały otwarte, których daty wyznaczało wiccańskie Koło Roku ${ }^{21}$, miały miejsce w Warszawie, zawsze na otwartej przestrzeni. W przypadku rytuałów misteryjnych nie jest to regułą. Bywa, że są one odprawiane w mieszkaniach wyznawców.

${ }^{18}$ Wnioski autorki poczynione na podstawie przeprowadzonych obserwacji i wywiadów.

${ }^{19}$ Czas mityczny w religii wiccan wskazuje na opowieść o Słonecznym Bogu i Trójjednej Bogini. Kolejne zmiany zachodzące w przyrodzie są tłumaczone poprzez mit, według którego Bogini wychodzi z podziemia na wiosnę, łączy się z Bogiem jako kochanka i żona, czym rozpoczynają nowy okres wegetacyjny. W lecie brzemienna Bogini-Królowa składa w ofierze Boga-Króla, którego następnie przywraca do życia. Ofiara pozwala na zasilenie energią ludzkich plonów, jednak Bóg w momencie śmierci obejmuje tron podziemia, przez co rozstaje się z Boginią. W równonoc jesienną tęsknota małżeństwa jest tak duża, że Król Podziemia podbija królestwo Bogini i zabiera ją do siebie. Oboje czekają tam na narodziny potomka, które rozpoczną nowy cykl roczny w przesilenie zimowe (Koło roku. Mit i mistyczna opowieść).

${ }^{20}$ Zazwyczaj podczas bądź przed rozpoczęciem rytuału następuje wypowiedzenie intencji, co z kolei jest zabiegiem typowo magicznym.

${ }^{21}$ Koło roku to inaczej wiccański kalendarz wyznaczający czas ośmiu sabatów. Cztery święta związane są z wydarzeniami astronomicznymi (przesilenia i równonoce). Cztery pozostałe związane są z kulturą pasterską i rolniczą (np. wyznaczają żniwa). Czarostwo jest religią naturalną, więc czas celebracji wskazuje przyroda. Koło Roku to próba zharmonizowania się z rytmem otaczającego świata oraz powrotu do pogańskich korzeni Europy. Nazwy świąt zostały zaczerpnięte głównie z obrzędowości celtyckiej. Wyjątek stanowi Lammas, przez celtów nazywane Lugha (Gąssowski 1987: 18). Należy jednak pamiętać, iż religię Celtów kultywują współcześni druidzi. Wiccanie jedynie zapożyczają nazwy i postaci mitologiczne z różnych religii, w tym celtyckiej. 
Schemat wykonywanych czynności przy obrzędzie otwartym jest taki sam jak dla rytuału inicjowanych czarownic. Rozpoczyna go arcykapłan bądź arcykapłanka, zamieniając przestrzeń profanum w przestrzeń sacrum ${ }^{22}$. Odbywa się to poprzez oczyszczenie na płaszczyźnie materialnej i duchowej - według wyznawców sfera sacrum powinna być wolna od wszelkich zanieczyszczeń. Niewidzialnych nieczystości prowadzący pozbywają się za pomocą kadzidła bądź miotły z witek. Istotne znaczenie ma też uprzątnięcie przestrzeni w sensie jak najbardziej dosłownym, oraz nadanie jej odpowiedniej aury: „Przed rytuałem powinno się wszędzie posprzątać. (...) Zadbaj zarazem, żeby otoczenie było chociaż trochę czarownicze, dzięki kadzidłu i świecom a może idolowi albo nawet kwiatom" (Lipp: 26).

Warszawska grupa obrzędowa wcześniej przygotowała ołtarz, na którym znajdowały się: athame ${ }^{23}$, nóż z białą rękojeścią, kadzielnica, miseczki z wodą i solą, ciasto i wino, figurki Bogów, pentakl, różdżka i dwie świece. Dodatkowo w czterech miejscach ustawiono gliniane znicze reprezentujące cztery żywioły i cztery strony świata.

Oczyszczenie energetyczne ${ }^{24}$ nie kończy się na użyciu miotły i kadzidła. Kolejnym krokiem jest wykorzystanie zaklętej uprzednio wody i soli, których ceremonialne kropienie i sypanie jednocześnie uświęca miejsce obrzędu. Następnie uczestnicy okadzają się i obmywają, aby stanąć wokół świętego ognia - swego rodzaju axis mundi rytualnego mikrokosmosu. Arcykapłanka dopiero wtedy zakreśla magiczny krąg przy pomocy athame, wypowiadając odpowiednią formułę magiczną. Tym samym zapewnia bezpieczeństwo całej grupie (zatoczenie kręgu spełnia funkcję apotropaiczną w wielu religiach i tradycjach magicznych $)^{25}$ i wyznacza dualizm sacrum - profanum ${ }^{26}$. Warto przeanalizować hierarchię wykonywanych czynności: oczyszczenie uczestnika znajduje się przed aktem zakreślenia kręgu, co pozwala domniemać, iż magiczny krąg stanowi dla czarownic metaforę świątyni. Potwierdzają to również wypowiedzi badanych, z których wynika, iż wejście do kręgu inicjuje kontakt z boskością. Wiele źródeł wskazuje też na pojmowanie przez wiccan przestrzeni kręgu jako „miejsca pomiędzy światami” (Por. Lipp: 25).

Rytuał rozpoczyna się, kiedy arcykapłanka wypowiada słowa modltiwy otwierającej. Od tego momentu język performatywny zaczyna odgrywać ogromną rolę w całościowym działaniu magicznym. To poprzez inwokację wzywane są cztery żywioły z czterech stron świata, duchy miejsca i sami bogowie. Po przywołaniu istot nadnaturalnych następuje wypowiedzenie intencji - zaklęcia. Często jest ona związana z aktualną fazą księżyca (księżyc przybywający sprzyja zaklęciom wspierającym nowe projekty, by nabierały mocy i wzrastały wraz z nim; w czas pełni projekty rozpoczęte podczas nowiu stają się dojrzałe i można zbierać ich plony, zaś wraz z księżycem ubywającym pozbywać

${ }^{22}$ Sacrum rozumiem za M. Eliade jako sferę, w której człowiek doświadcza świata w sposób symboliczny i mistyczny, w której łączy się z rzeczywistością sakralną (Eliade 1999: 6).

${ }^{23}$ Athame to ceremonialny sztylet, zwykle obusieczny i jest jednym z ośmiu podstawowych narzędzi czarownic (Adler 1986: 584)

${ }^{24}$ Współczesne czarownice są na bieżąco z osiągnięciami nauki, respektują je i korzystają z dobrodziejstw technologii. Pojęcia nadnaturalne traktują bardziej abstrakcyjnie, często korzystając z nazewnictwa środowisk ezoterycznych czy kultur Wschodu. Wnioski autorki poczynione na podstawie przeprowadzonych obserwacji i wywiadów.

${ }^{25}$ Rytualne zamknięcie stwarza barierę zabezpieczającą człowieka stojącego w środku od nieprzyjaznych mu sił będących na zewnątrz (wykorzystanie magicznego kręgu i jego ochronnych oraz uświęcających właściwości opisuje Kazimierz Moszyński, odwołując się do tradycji ludowej. Zob. Moszyński 1968: 322). Podobną rolę spełnia pierścień lub wieniec. Wieniec chronił podczas obrzędów otwartych na sferę mediacji „,najważniejszą część ciała tzn. głowę (Moszyński 1968: 319).

${ }^{26}$ „Sacrum w kręgu bywało różne; krąg nie łączył się z istotą wierzeń, a więc z wewnętrzną treścią kręgu, lecz treść tę odgraniczał od przestrzeni świeckiej, niezależnie od czasu i kultury” (Zob. Krzak, Kowalski: 43). 
tego, co niechciane). Sprawcza moc słowa łączy się płynnie z gestami arcykapłanki ${ }^{27}$, symboliką materii ${ }^{28}$ i aktami wspólnototwórczymi ${ }^{29}$.

\section{Znaczenie slowa $w$ rytualach wicca}

Na podstawie analizy wiccańskiego rytuału otwartego możemy wyróżnić kilka niezbędnych elementów decydujących o jego skuteczności. Analogicznie do odległych w czasoprzestrzeni zabiegów magicznych, badanych wśród kultur pierwotnych, konstytutywną funkcję spełnia tu słowo. Bez odpowiedniej werbalizacji rytuał nie może się rozpocząć ani skończyć, to poprzez język dokonuje się część religijna obrzędu (przybycie bogów do świętego kręgu), uruchomienie ,akcji magicznej” (Buchowski 1993: 123) i wyznaczenie świętej przestrzeni. Badani opisują znaczenie słowa w rytuale oraz w życiu codziennym następująco:

\section{J.K: Czym jest dla Was stowo? Dlaczego zaklęcia sa tak ważne?}

Anna: Niektórzy mówia, że stowa kreuja rzeczywistość i ja się z tym zgadzam. Słowo samo w sobie jest już zaklinaniem rzeczywistości, słowa sa energia, która oddziałuje na to, co nas otacza. Tworzymy słowem - słowo to jedna z największych ludzkich mocy, możemy nimi wyrażać swoja wolę i jak powiemy, tak będzie. Stowo w rytuale jest niezbędne - to ono pozwala czarownicy ukierunkować moc i energię, ustanowić święta przestrzeń, wypowiedzieć intencję, inwokować Bogów. Stowo to magia sama w sobie, słowo to potęga. Z jednej strony uważam więc na to, co mówię czy myśle na co dzień, żeby tworzyć wspierajacy dla mnie świat. Podczas rytuatu zaś stowa staja się sztuka, częścia magicznego rzemiosła - im bardziej kunsztowne, trafne, celne, pięknie, tym większa moc rytualu (wyw. IV, Anna).

J.K: Jakie znaczenie maja stowa wypowiadane podczas obrzędu?

Magdalena: Sa uroczyste, tak jak uroczyste sa szaty rytualne. Kolejne narzędzie dla człowieka, dla podświadomości. Maja wprowadzić odpowiedni nastrój, sa tez wyrazem szacunku dla bogów. Nie bez powodu chrześcijanie ubieraja najlepsze garsonki w niedziele, kiedy ida do kościoła. Od wieków w różnych kulturach obrzędy magiczne i rytualne sa „, ubierane” $w$ odpowiednie słowa, bo tego po prostu wymaga sytuacja (wyw. II, Magdalena).

Jak zauważa Edward Sapir, perspektywa magicznego postrzegania świata zakłada „odczucie identyczności lub bliskiej odpowiedniości słowa i rzeczy” (Sapir 2003: 243). „Rzeczywiste znaczenie” formuły magicznej można odgadnąć jedynie przez analizę w świetle sprawczej mocy słów (Malinowski 1987: 102-103). Jednakże do tej pory badacze upatrywali jej jedynie w języku używanym podczas działań obrzędowych i magicznych, głównie dlatego, że badali magię słowa występującą w kulturach tradycyjnych. Według Michała Buchowskiego społeczności pierwotne, sięgając po szeroko rozumianą magię, nie sprowadzają jej tylko do słowa, lecz konieczna jest pewna ,,procedura konwencjonalna”, według której magiczne formuły muszą zostać wyartykułowane ,przez odpowiednią osobę w odpowiednich warunkach" (Buchowski 1993: 114). W rozumieniu człowieka pierwotnego rytuał magiczny jest „sekwencją słów, mniej lub bardziej tajemniczych, znanych już od niepamiętnych czasów (...), przekazywanych przez ogólnie uznanego czarownika" (Malinowski 2003: 242).

${ }^{27}$ Podczas rytuału arcykapłanka wykonuje czynności mające znaczenie magiczne, jak np. włożenie athame (sztyletu) do kielicha z winem, co symbolizuje świętą unię boga i bogini. Sztylet to przedmiot falliczny, odnoszący się do męskości; kielich symbolizuje kobiecość.

${ }^{28}$ Narzędzia używane podczas rytuału nie są przypadkowe, każdy przedmiot posiada swoje symboliczne znaczenie. Sztylet athame to reprezentant pierwiastka męskiego, kielich - żeńskiego. Świeca symbolizuje żywioł ognia, kadzidło - powietrza, misa z wodą - wody, sól - ziemi.

${ }^{29}$ Mowa o dzieleniu się w kręgu ciastem i winem. Dzielenie się jedzeniem i piciem zazwyczaj staje się aktem więziotwórczym, mamy do czynienia z symboliką biesiadną, communitas jest budowane przez rozdzielenie między uczestników ciasta i alkoholu. 
Anna Engelking zauważa, iż skuteczność tak rozumianej magii oralnej opiera się na konglomeracie mocy konwencji i mocy wiary w siły nadprzyrodzone (Engelking 2000: 53). Odwołujące się do sfery sacrum formuły nadają przedmiotom magiczny status na drodze konkretnego rytuału.

W wicca nastąpiła synteza światopoglądu mitycznego i postmodernistycznego, co pozwoliło zaistnieć językowi performatywnemu w jego kompletnym kształcie - kiedy jest on „narzędziem działania, a nie narzędziem refleksji” (Malinowski 2000: 22).

Przyjrzyjmy się oralnym formułom wypowiadanym podczas obrzędów otwartych. Magia werbalna rozpoczyna się w momencie zakreślania kręgu, kiedy arcykapłanka wypowiada słowa:

\section{Czarodziejski kręgu mocy}

Kreśle cię i zaklinam moja moca

Byś wyznaczyt święta przestrzeń

I stat się granica pomiędzy światami

Chroń nas i moc, która w Tobie wzniecamy

W imię Rogatego Władcy Puszczy i Księżyca Pani ${ }^{30}$.

Idąc za myślą Jean’a Derive, język performatywny wykorzystywany w rytuale może spełniać dwie funkcje: kreacyjną bądź szkodliwą, wszystko zależy od intencji czarownika (Derive 2003: 264). W kulturach oralnych osoba zajmująca się magią posiada władzę werbalną - moc sprowadzania szczęścia bądź nieszczęścia (Derive 2003: 264). Jak stwierdza Gerardus van der Leeuw, zaklęcie stanowi „decydującą moc”, istnieją też zabiegi lingwistyczne pozwalające je wzmacniać: akcent, podniesienie głosu, rytm, rym, powtórzenia „wszystko to nadaje słowu wzmożoną energię" (van der Leeuw 2003: 325).

Pamiętając o funkcji aktu zakreślania kręgu, arcykapłanka wypowiadająca przytoczone zaklęcie chroni uczestników, kreuje sferę sacrum, przez czarownice zaczyna być uznawana za jednostkę zdolną do kontaktu z wyższymi bytami - mówiąc krótko, odpowiada opisowi czarownika dzierżącego władzę werbalną w kulturach tradycyjnych. Analizując treść formuły, warto zwrócić uwagę na podmiotowy charakter kręgu, do którego mówiący zwraca się bezpośrednio. Informuje, co robi i w jaki sposób (kreślę cię $i$ zaklinam moja moca), po co to robi (byś wyznaczyt święta przestrzeń $i$ stat się granica pomiędzy światami), używa dyrektywy służącej zaznaczeniu, jaki cel chce osiągnąć (chroń nas i moc, która w tobie wzniecamy), wreszcie oświadcza, iż działa w imieniu wyższych bytów - Rogatego Władcy Puszczy i Księżyca Pani. Wszystkie opisane elementy wskazuje Deborah Lipp:

„Słowa zaklęcia powinny zawierać następujące elementy:

- To, co robisz

- Bądź konkretny/a Jak to robisz

- Co chcesz osiągnąć/ czego oczekujesz

- I powinno to też dobrze brzmieć

Inwokacje mają też zły zwyczaj, czasami robią się długie i skomplikowane. Mocno wierzę w język, który jest zwięzły (konkretny), bo częściej osiąga rezultaty. Możesz nawet rymować, to sztuczka od dawna związana z czarostwem”. W magii im bardziej konkretny jesteś, tym bardziej konkretny jest rezultat (Lipp 2003: 95).

Wiccanie, posługujący się językiem performatywnym w rytuale, świadomie używają opisywanych przez van der Leeuw’a zabiegów lingwistycznych. Ton wypowiadanych podczas obrzędu formuł jest zazwyczaj podniosły, artykulacja głośna, dobitna i rytmiczna, jak zobaczymy w kolejnych przykładach - nierzadko występuje wspomniana przez Lipp „sztuczka” zastosowania rymu. Oprócz tego autorka zaznacza, jak ważne dla

\footnotetext{
${ }^{30}$ Treść zaklęć pochodzi z materiałów zebranych podczas badań.
} 
skuteczności zaklęcia jest, aby wypowiedź była konkretna. Odbiega to od wizji Malinowskiego opisującego język magiczny kultur tradycyjnych jako nielogiczny, tworzony „według jakichś niespotykanych zasad lingwistycznych" (Malinowski 1986: 546). Fundamentem magii oralnej współczesnych czarownic okazuje się być precyzyjna i rzeczowa retoryka, ubrana jednak w uroczysty ton i szereg środków stylistycznych.

Wracając do apostrofy użytej przez czarownicę zakreślającą krąg - wskazuje na relację między specyficznym bytem, jakim staje się magiczny krąg a osobą dzierżącą władzę werbalną. Najbardziej pierwotne wykorzystanie magii słowa opiera się na przeświadczeniu, że siły nadprzyrodzone nie tylko istnieją, ale pewne zdania, formułowane w odpowiedni sposób, pozwalają nimi sterować (Frazer 2012: 51-55). Według koncepcji Jamesa Frazer’a słowo wykorzystywane w obrzędzie można podzielić na takie, które stanowi akt sakralny i język stanowiący akt magiczny. Głównej różnicy badacz upatruje w postawie mówiącego - w przypadku aktu sakralnego jest ona pełna pokory i zależności wobec sacrum, zaś akt magiczny wyraża zależność, według której sacrum znajduje się na usługach człowieka (Frazer 2012: 51-55). Mamy więc do czynienia z połączeniem obu wariantów - arcykapłanka zaznacza swoją władzę nad magicznym kręgiem, zaklinając go swoją mocą. Informuje jednak z pokorą, iż działa w imieniu bogów, jakby tak wielka moc nie mogła należeć jedynie do człowieka.

Malinowski, opisując działanie magii oralnej na przykładzie zaklęcia wayugo (stanowiącego część magii czółna), stwierdza, iż zaklęcia stanowią „instrument służący do specjalnych celów, a ich wartość zależy od skuteczności i szczególnej władzy, jaką sprawują nad rzeczami” (Malinowski 1986: 546).

Tym razem za przykład posłuży nam formuła magiczna mająca na celu oczyszczenie i pobłogosławienie wody oraz soli:

Wodo Źródlana, przez moc płynaca z Księżyca, któremu podlegasz, wypędzam z Ciebie wszystkie zanieczyszczenia. Solo kamienna, przez moc ukryta w Ziemi, z której pochodzisz, święcę Cię i proszę, abyś przyniosła nam swoje tajemne błogostawieństwo ${ }^{31}$.

Tekst po raz kolejny wskazuje na postawę pokory wobec pewnych energii, w tym wypadku Księżyca i Ziemi ${ }^{32}$. Materia używana podczas rytuału (sól i woda) przez słowo zmienia się w reprezentanta sił Potrójnej Bogini ${ }^{33}$ manifestującej się w rzeczywistości jako Ziemia i Księżyc. Tym razem czarownica nie dokonuje transformacji przez własną moc - cały proceder odbywa się przy użyciu potęgi bóstwa, co może być spowodowane bliskim powiązaniem symbolicznym soli i wody z żywiołami ${ }^{34}$. Te z kolei zajmują w wicca szczególne miejsce. Woda i Ziemia podlegają bogini, zaś powietrze i ogień - Rogatemu Bogu ${ }^{35}$.

${ }^{31}$ Treść zaklęć pochodzi z materiałów zebranych podczas badań.

${ }^{32}$ Co do terminologii używanej w artykule przyjmuję następującą zasadę: pisząc o księżycu jako ciału niebieskim, używać będę małej litery, natomiast jako personifikacji Bogini lub aspektów boskości - wielkiej. To samo tyczy się pojęcia natury/Natury oraz żywiołów w rozumieniu powszechnym lub sakralnym.

${ }_{33}$ Potrójna Bogini Księżyca uosabia boskość w wymiarze kobieco-lunarnym. Związek między kobiecością a lunarnością jest akcentowany w wielu kulturach. Wiccanie szczególnie zwracają uwagę na mistyczne połączenie cyklu księżyca z cyklem menstruacyjnym. Jeden i drugi liczy 28 dni. Zjawisko analizuje dokładnie badacz francuski Jean-Paul Rox w dziele Krew. Mity, symbole, rzeczywistość (Zob. Roux 1994: 8). Ponadto trzy główne fazy księżyca odzwierciedlają etapy kobiecego życia, reprezentowane przez archetypiczne postaci Potrójnej Bogini: Dziewicę (księżyc przybywający), Matkę (księżyc w pełni) i Wiedźmę/ Staruchę (księżyc ubywający). Taką koncepcję kobiecego bóstwa wiccanie przejęli od Roberta Graves'a, który w książce Biała Bogini opisuje ów archetyp występujący w mitologiach różnych kultur (Por. Graves 2008).

34 Trzonem magii w tradycji wicca jest zasada sympatii. „Wszystko, co jest podobne do danej rzeczy, jest z nią w sympatii i może zostać użyte do jej reprezentowania" (Lipp 2003: 16). Ten mechanizm pozwala używać narzędzi jako symbolicznych przedstawicieli żywiołów (np. sól - ziemia, kadzidło - powietrze, świeca - ogień itp.).

${ }^{35}$ Rogaty Bóg reprezentuje męską część dwoistego systemu teistycznego, którym charakteryzuje się wicca odłamu tradycyjnego. Połączony z cyklem życia i śmierci, naturą, dzikością, seksualnością i łowami. Rogi mają eksponować zjednoczenie człowieka i zwierzęcia (Por. J.Farrar, S.Farrar 1989: 32-34). 
Wszystkie cztery „opisują wszechświat i wszystko, co w nim zawarte” (Lipp 2003: 15), stanowią symboliczną wizję świata ${ }^{36}$. Do uświęconej przestrzeni kręgu wzywa się je poprzez inwokacje:

W zachodniej stronie, ja Ciebie wzywam, do kręgu tego moc Twa przyzywam.

Wodo czysta z rwacego strumienia, przynieś uczucie i moc oczyszczenia.

$\mathrm{Na}$ Twe przybycie teraz czekamy, bądź nam ochrona! Z pokłonem witamy! ${ }^{37}$

Pozostałe trzy zaklęcia posiadają analogiczną strukturę: informują o kierunku świata, z którego „pochodzi” dany Żywioł, sferze życia, którą się opiekuje, przyzywają jego moc do przestrzeni sacrum i w sposób imperatywny oznajmiają, jakie zadanie ma spełnić podczas obrzędu, jednocześnie wyrażając szacunek wobec nadnaturalnego bytu poprzez zwrot $Z$ pokłonem witamy! Inwokacja żywiołów to jeden z najbardziej rozpoznawalnych elementów wiccańskiego rytuału.

Nieprzypadkowo w analizowanym zaklęciu użyto tylu epitetów i sposobów na określenie Żywiołu. W rozumieniu czarownic idealna inwokacja powinna zawierać tyle różnych obrazów, skojarzeń i powiązań jak to tylko możliwe, żeby zwrócić uwagę wzywanego bytu i zaznaczyć, o kogo dokładnie chodzi (Lipp 2003: 117). Oprócz tego dyrektywy mają sprawiać wrażenie konieczności, a pochlebstwa i wyrazy szacunku zachęcić istoty nadprzyrodzone do przybycia i otoczenia wyznawców opieką. „Te czynniki - konkretność, opisowość, pochwała i potrzeba - składają się na doskonałe i potężne inwokacje" (Lipp 2003: 117). Rzecz ma się podobnie z pożegnaniem Żywiołów czy też związanych $\mathrm{z}$ nimi bytów pod koniec rytuału:

O mocy Ognia, co byłaś wśród nas, kończyć rytuat nadszedt już czas.

Za ochronę kręgu dzięki Wam składamy, odejdźcie w pokoju, z pokłonem żegnamy!38

Aby nie zniechęcić do siebie potężnych istot i nie narazić się na ich gniew, wiccanie pilnują, aby podziękować za ich działania i oddać należny im szacunek przy zakończeniu magicznych zabiegów.

Schemat rytuału zakłada inwokację bogów po inwokacji żywiołów. Zasada kreowania zaklęcia jest ta sama: konkretność, opisowość, pochwała i potrzeba. Przykładową formułę zapraszająca bóstwa do magicznego kręgu podaje Lipp:

Najłaskawsza Bogini, Potężny Rogaty, Ukochani Panie i Pani wystuchajcie nas! Wielka Matko o wielu aspektach. Pani Księżyca, Matko Ziemi, Panno, Matko i Starucho. Wspaniała dawczyni płodności; źródło naszego życia! Bądź tu z nami.

Potężny Rogaty o wielu aspektach. Ojcze polowania. Panie Śmierci i Odrodzenia, jasny i ciemny, o dwóch obliczach. Cudowny dawco światta. Ty, który wszystko zapładniasz! Bądź tu z nami.

Panie i Pani, przyjmijcie ten święty rytuat. Badźcie naszymi przewodnikami i chrońcie nas, gdy my, wasze dzieci, czcimy Was na stary sposób. Witajcie i badźcie błogosławieni (Lipp 2003: 152).

Istotnym aspektem magii słowa w wiccańskim rytuale jest również sakramentalny zwrot Niech tak się stanie! podkreślający sprawczą moc języka. Wypowiada się go na końcu wszelakich oświadczeń woli, które mają miejsce podczas magicznego działania np. Nowo narodzone Stońce, przynieś nam obfitość i bogactwo, w każdym jego wymiarze! Niech tak się stanie!

Zawołanie spełnia dodatkową funkcję wzmacniającą siłę zaklęcia, obok intonacji czy powtórzeń. Mówiąc o tych ostatnich, nie sposób pominąć zabiegu trzykrotnego

\footnotetext{
${ }^{36}$ Jak opisuje to Deborah Lipp: „Dają nam systematyczne podejście do poznania niepoznawalnego. Zapewniają nam system wzajemnych powiązań, a magia polega na wzajemnych powiązaniach” (Lipp 2003: 15).

${ }^{37}$ Treść zaklęć pochodzi z materiałów zebranych podczas badań.

${ }^{38}$ Treść zaklęć pochodzi z materiałów zebranych podczas badań.
} 
powtórzenia, widocznego w przytaczanej przez Lipp formule uświęcania kadzidła symbolizującego żywioł Powietrza:

Przez święte imiona, przez święte imiona, przez święte imiona! Przeznaczam i poświęcam Cię, o Powietrze, o Umyśle, o Inspiracjo. Przynieś swoje szczególne błogosławieństwo temu naszemu świętemu rytowi (Lipp 2003: 94).

Liczba trzy od zarania dziejów posiada magiczne właściwości. Jego niezwykła moc może wynikać z dodatkowych znaczeń: w wicca związana z trójpostaciowością bogini i przepływem w Naturze. Trójka to cykle: narodziny - śmierć - odrodzenie; młodość dojrzałość - starość, początek - środek - koniec. Trzykrotne powtórzenie w języku magicznym wskazuje na istotę trójki jako liczby kończącej cykle i spełniającej pragnienia.

Analizując przytoczone formuły magiczne, możemy zauważyć, że pomimo rzeczowości, opisowości i logiki, którą się charakteryzują, ich język znacznie różni się od mowy potocznej. Niektóre wyrazy występują w odmiennej, podniosłej postaci (,przybądź” zamiast „przyjdź” czy „składamy dzięki” zamiast „dziękujemy”). Gramatyka i stylistyka również nie przypomina tej używanej na co dzień (chociażby rymy czy przestawiony szyk zdania). Wszystko to pozwala określić język performatywny w wiccańskim rytuale jako „tajemnicze i święte słowa, sprawujące władzę nad rzeczywistością” (Malinowski 2003: 242). Język w magii, zarówno tej współczesnej jak i pierwotnej, jest czymś szczególnym, tworzy relację człowieka z rzeczywistością, przedmiotem czy bóstwem. To samowystarczalny byt zawierający istotę rzeczy, będący jednocześnie znakiem i jego desygnatem (Malinowski 2003: 244). Zaklęcie może być rozpatrywane tylko w kontekście magicznym i rytualnym, aczkolwiek sama moc słowa - niekoniecznie. Czarownice upatrują jego sprawczości w każdej codziennej sytuacji, co nie wyklucza wyjątkowości i szczególnej siły werbalizowania zaklęć w rytuale.

Struktura zaklęć i inwokacji w wicca przypomina ludową magię słowa definiowaną przez Annę Engelking jako symboliczno - pragmatyczną. Z jednej strony zawsze związaną ze sferą sacrum, umożliwiającą kontakt z tajemnicą i światem nadprzyrodzonym, z drugiej praktyczną i użytkową, obfitującą w rozkazy, polecenia czy prośby (Engelking 2003: 55). Pod wieloma względami magia oralna praktykowana w społeczeństwie postindustrialnym nie różni się od tej badanej w społecznościach tradycyjnych. Zawiera silny ładunek emocjonalny, o którym pisał już Bronisław Malinowski (Malinowski 2003: 246) i zamyka w sobie szereg informacji na temat systemu wierzeń czarownic i ich symbolicznej wizji świata, przez co może być rozumiana jako zjawisko kulturowe, nie tylko werbalne ${ }^{39}$.

\section{Bibliografia}

Adler, M. (1986). Drawing down the Moon. Witches, Druids, Goddess-Worshippers, and Other Pa-gans in America Today, Revised and Extended Edition. New York: Beacon Press.

Austin, J. (1975). How to do things with words. Second Edition. Cambrige: Harvard University Press.

Buchowski, M. (1993). Magia i rytuat. Warszawa: Wydawnictwo Instytutu Kultury. Czerwiński, M. (1975). Magia, mit, fikcja. Warszawa: Wiedza Powszechna.

${ }^{39}$ Marcin Czerwiński wskazywał na ogromną rolę, jaką odgrywa magia językowa w tradycji ludowej. Notuje, iż nie stanowi ona autonomicznej dziedziny, ale „tkwi w całości rytuałów właściwych danej kulturze” (Czerwiński 1975: 29). 
Derive, J. (2003). Stowo i władza w kulturze oralnej. W: G. Godlewski (red.), Antropologia stowa. Zagadnienia i wybór tekstów (s. 257 - 266). Warszawa: Wydawnictwo Uniwersytetu Warszawskiego.

Eliade, M. (1999). Sacrum i profanum. O istocie religijności (przeł. R. Reszke). Warszawa: Wydawnictwo KR.

Engelking, A. (2010). Klątwa. Rzecz o ludowej magii stowa. Warszawa: Oficyna Naukowa. Ennena, Co to jest jest wicca? Pozyskano z http://www.wicca.pl/?art=13.

Farrar, J. Farrar, S. (1989). The Witches' God: Lord of the Dance. London: Robert Hale. FrAZER, J.G. (2012). Złota gałąź (przeł. H. Krzeczkowski). Kraków: Wydawnictwo vis-a-vis. Gąssowski, J. (1987). Mitologia Celtów. Warszawa: Wydawnictwa Artystyczne i Filmowe. Graves, R. (2008). Biała Bogini (przeł. I. Kania). Warszawa: Aletheia.

GrZEgORCZYKowa, R. (1995). Jak rozumieć kreatywny charakter języka. W: R. Tokarski, M. Lewicki (red.), Kreowanie świata w tekstach (s. 13-24). Lublin: Wydawnictwo Uniwersytetu Marii Curie - Skłodowskiej.

Koło roku. Mit i mistyczna opowieść. Pozyskano z http://wiccanski-krag.com/kociolek-inspiracji/kolo-roku/.

LeVI - Strauss, C. (1969). Myśl nieoswojona (przeł. A. Zajączkowski). Warszawa: PWN. Malinowski, B. (1987). Ogrody koralowe i ich magia (przeł. B. Leś). Warszawa: PWN.

Malinowski, B. (1986). Potęga stów w magii. Niektóre dane językowe. W: A. Waligórski (red.), Argonauci Zachodniego Pacyfiku (s. 549). Warszawa: PWN.

Malinowski, B. (2000). Problem znaczenia w jezykach pierwotnych. W: K. Pisarkowska (red.), Językoznawstwo Bronisława Malinowskiego. T. 2 (s. 22). Kraków: Universitas.

Malinowski, B. (2003). Stowo w kontekście działania. W: G. Godlewski (red.), Antropologia stowa. Zagadnienia i wybór tekstów (s. 113-124). Warszawa: Wydawnictwo Uniwersytetu Warszawskiego.

Moszyński, K. (2010). Kultura ludowa Słowian. T. II, z. 2: Kultura duchowa. Warszawa: Graf_ika.

O nas. Pozyskano z http://wiccanski-krag.com/kociolek-inspiracji/kolo-roku/.

OKraska, R. (2001). W kręgu Odyna i Trygława. Biała Podlaska: Wydawnictwo Rekonkwista.

PeŁka, L. (1999). Współczesne neopogaństwo słowiańskie (rodowody - doktryna - kult). „Przegląd Religioznawczy”, 3/4, 115-133.

PeŁka, L. (2000). Od kultu Matki Bogini do wicceanizmu (czarownica wczoraj a dziś). W: J. Wrzesiński (red.), Czarownice. Funeralia lednickie 2 (s. 21-36). Wrocław-Sobótka: SNAP Poznań.

RiESMAn, D. (2003). Tradycja oralna a stowo pisane. W: G. Godlewski (red.), Antropologia słowa. Zagadnienia $i$ wybór tekstów (s. 396-402). Warszawa: Wydawnictwo Uniwersytetu Warszawskiego.

SAPIR, E. (2003). Język. W: G. Godlewski (red.), Antropologia słowa. Zagadnienia i wybór tekstów (s. 49-58). Warszawa: Wydawnictwo Uniwersytetu Warszawskiego.

Straczuk, J. (2006). Cmentarz i stół. Pogranicze prawostawno-katolickie w Polsce i na Białorusi. Wrocław: Wydawnictwo Uniwersytetu Wrocławskiego.

Tomasiewicz, J. (1994). Stare religie nowej ery. „Nomos. Kwartalnik Religioznawczy”, $5 / 6,99$. 
van der Leeuw, G. (2003). Słowo święte i uświęcajace. W: G. Godlewski (red.), Antropologia stowa. Zagadnienia i wybór tekstów (s. 325-332). Warszawa: Wydawnictwo Uniwersytetu Warszawskiego.

WASILEWSKI, J.S. (1989). Tabu a paradygmaty etnologii. Rozprawa habilitacyjna. Warszawa: Wydawnictwo Uniwersytet Warszawski.

Witulski, M. (2009). Próba zdefiniowania i usystematyzowania ruchu Wicca. „Państwo i Społeczeństwo", 4, 5-22.

\section{Spis wywiadów}

1. I - wywiad z Nefre (pseudonim), wiccanką praktykującą magię w polskim kowenie tradycyjnym

2. II - wywiad z Magdaleną, wiccanką praktykującą magię w polskim kowenie tradycyjnym

3. III - wywiad z Marią, wiccanką eklektyczną

4. IV - wywiad z Anną, wiccanką praktykującą magię w polskim kowenie tradycyjnym 


\section{JAGODA KUREK}

\section{THE MEANING OF THE WORD IN WICCA MAGIC RITUALS}

The article aims to analyse the language of magic used during the Modern Wiccan ritual. The author claims that the contemporary practitioners of magic within social and religious movements prove that functioning of the mythical worldview in the post-industrial society is possible. It opens the opportunity for considering the essence of the word's magic in a completely new dimension: it is about the exploration of the living phenomenon present in Polish culture for over twenty years. The theoretical context of this study relies on the most important anthropological concepts regarding the magical word (for example Malinowski, Buchowski, Engelking). The interpretation of the spells, prayers and invocations is possible thanks to the author's field studies. Moreover, observations, interviews and analyses of the existing sources enables presenting the characteristics of the wide cultural phenomenon such as Wicca. The list of the interviews can be found at the end of the article. 